\title{
6. Changing a redistributive policy: renewal of fiscal equalization
}

In federations, fiscal equalization aims at balancing fiscal disparities between levels and jurisdictions resulting from the territorial variation of economic development and societal conditions. The redistribution of revenues between federal and state governments and among states follows principles entrenched in the constitution and rules defined by federal law. In general, the money transferred is not provided for specific purposes, although special grants can have equalizing effects.

For a long time, fiscal equalization of fiscal transfers between governments has been considered as a technical matter of public finance. Scholars have debated about the need for equalization, as well as further related matters such as the appropriate extent and criteria of redistributing fiscal revenues, the consequences of equalization for fiscal policy of constituent units, and the economic effects for the federation (Boadway and Shah 2007). From a normative point of view, fiscal equalization implies a trade-off between autonomy and distributive justice. It aims 'at reducing fiscal inequalities between constituent units without threatening their fiscal and policy-making autonomy' (Béland and Lecours 2014: 304). Whereas a balance of these basic institutional principles is entrenched in the federal constitution, the particular distribution of fiscal resources between governments is a matter of continuous political dispute. Decisions on the criteria of distributive justice among jurisdictions and the application of these criteria affects resources of governments. They are also a matter of concern for citizens. As taxpayers, they expect that their money is spent by the government they have elected. As beneficiaries of public services, they expect to be treated as equals regardless of where they live. The first expectation is addressed to state governments, the second to the federal government. For this reason, these redistributive decisions need to include all governments in joint decisions, and they need to be legitimized in democratic processes within governments.

Multilevel governance and democratic legitimacy of fiscal equalization complicates decision making on a redistributive policy for three reasons. First, as it affects fiscal resources of all governments in a federation, there are good reasons that all governments have a say and that they negotiate an agreement. Although the design of a fiscal equalization system must finally, as a rule, pass 
in the form of federal legislation, the proposal for legislation should express a consensus among all governments. De facto, if not according to institutional rules, fiscal equalization is a matter of joint-decision making. Second, executives negotiating an intergovernmental agreement are accountable to parliaments, and members of parliaments or parties in parliament speak and act for the people of a jurisdiction. Therefore, negotiating executives have all incentives to bargain for the profit of their government and their people and to prevent all decisions leaving them worse off. Third, although executives tend to behave as rational egotists, they have to justify their bargaining position by norms of distributive justice. However, in contrast to many other instances of distribution in societies (Walzer 1983), there is no single norm that applies for fiscal equalization. Instead, different norms are appropriate. This follows from the conflict between autonomy and solidarity in federations. Depending on how these basic values are assessed and prioritized, redistribution of fiscal resources can be evaluated according to per capita equality, the needs of governments to provide public services, or efficiency of revenue collection and public spending.

In view of these obstacles for decision making, fiscal equalization appears as a least likely case of policy change, not to mention innovation. However, fiscal equalization has to be regularly adjusted and revised. Adjustment can be built into a system of fiscal equalization and then result from indicators of economic and societal changes determining how available resources are shared. However, the modes and the extent of equalization cannot be taken for granted. They express political decisions which are regularly disputed because assessments of parties differ and public opinion on fiscal equalization varies. Territorial effects of economic developments and a significant shift in fiscal burdens between governments due to new problems or tasks affecting jurisdictions differently are likely to prompt these disputes. Hence while rule-based adjustment stabilizes fiscal equalization, a revision has to be expected from time to time, and in fact the issue regularly appears on the agenda in federal systems. Revising equalization is, from the point of view of governments at least, a purely redistributive issue. Any change of fiscal equalization ends with winners and losers, with more or less significant effects for the individual governments. These effects have to be justified in parliaments and in public. In general, policies with redistributive effects are difficult to change in multilevel governance. The particular institutional conditions of politics of fiscal equalization increase the difficulties.

Nonetheless, when comparing established federal states, we discover change, which in some cases is significant and intended. As the following case studies on Germany, Australia and Switzerland demonstrate, fiscal equalization, when established, is regularly contested but is stabilized by the institutional conditions of joint-decision making, which usually combine 'technocratic', that is, 
expert dominated, intergovernmental processes and processes dominated by 'topocrats', that is, executives accountable to parliaments (for these categories see Beer 1978: 18). Due to institutional structures, the evolution of fiscal equalization is highly path-dependent, but innovation is nonetheless possible in processes of reform.

In all three selected federations we can observe processes ending with a reform of fiscal equalization. However, the outcomes of these processes in terms of scope and substance of change vary. In Germany, fiscal equalization was introduced in 1951, when the federal government started to provide grants to those Länder governments that had been particularly burdened by post-war immigration of refugees from Eastern Europe and by the division of East and West Germany. Since 1955, it is entrenched in the constitution. The law as well as the constitutional rules have been amended several times, and the system which exists nowadays resulted from a series of incremental changes (Feld and von Hagen 2007; Renzsch 1991). Redistribution leads to a significant equalization of revenues, while disparities in fiscal needs remain. In Australia, the federal government started to support states and territories in response to a secession referendum in Western Australia in 1933 and established the Commonwealth Grants Commission to institutionalize the task. The whole system was entirely revised in two reform steps in 1999 and 2007 and now combines revenue and need-based equalization. In Switzerland, the federal government supported the cantons by special grants. In 1991, the federal Department of Finance initiated an evaluation of transfers and discovered that, on balance, the rich cantons profited from these grants more that the poor cantons. A new system of fiscal equalization aiming at revenues and needs was enacted in 2008, in the course of a substantial reform of the federal constitution. Table 6.1 summarizes institutional conditions of fiscal equalization politics and policy change and the basic features of the system in the three federations.

\section{FISCAL EQUALIZATION IN GERMANY'S FEDERALISM REFORM}

In Germany, the Basic Law (Grundgesetz), the federal constitution, establishes fiscal equalization in order to reduce the dependence of Länder governments in less developed regions on federal grants. It should contribute to achieve equivalent living conditions for citizens in all regions of Germany, an aim which the mainstream parties appreciated as an essential element of the welfare state during the first two decades after World War II. After basic principles had been constitutionalized in 1955, a series of constitutional amendments made the rules of equalization increasingly detailed. They oblige the federal legislature to adjust the vertical allocation of the value added tax (VAT) revenues 
Table 6.1 Fiscal equalization in Germany, Australia and Switzerland

\begin{tabular}{lllll}
\hline & Institutional conditions & Policy change & $\begin{array}{l}\text { Basic features } \\
\text { of fiscal } \\
\text { equalization }\end{array}$ & $\begin{array}{l}\text { Fiscal disparities } \\
\text { and redistributive } \\
\text { effect of } \\
\text { equalization* }\end{array}$ \\
\hline Germany & $\begin{array}{l}\text { Federal law with veto } \\
\text { right of Bundesrat } \\
\text { (joint-decision making) }\end{array}$ & $\begin{array}{l}\text { Several gradual } \\
\text { adjustments (last }\end{array}$ & $\begin{array}{l}\text { Mainly revenue } \\
\text { equalization }\end{array}$ & $1.7 \rightarrow 1.1$ \\
\hline Australia & Intergovernmental & Reforms 1999 and & Revenue and & $7.5 \rightarrow 1$ \\
& agreement and federal law & 2007 significantly \\
& (joint-decision making in & changing the & needs-based \\
equalization & \\
& the shadow of hierarchy) & existing system and & & \\
& & continuous revision & & \\
& Constitutional amendment & New fiscal & Revenue and & $4.3 \rightarrow 2.6$ \\
& and federal law & equalization & needs-based & \\
(joint-decision making in & with effective & equalization & \\
& the shadow of majority & equalization effects & & \\
& [referendum] democracy) & (2008) & & \\
\hline
\end{tabular}

Note: * Fiscal capacity of richest state in relation to poorest state before and after fiscal equalization in 2012 (OECD 2013: 99-116).

in order to enable federal and Länder governments to cover their necessary expenditures, or, to put it in another way, to avoid a vertical fiscal imbalance. Moreover, they provide for a horizontal equalization of revenues of the Länder on a per capita basis. Third, the federal government can allocate additional general grants to Länder with special needs.

Before the last reform passed in 2017, horizonal equalization was meant as a transfer of finances from Länder with revenues above average per capita to Länder whose revenues fall short of average. To a certain extent, this was achieved by distributing part of the Länder share of VAT revenues. In addition, transfers from Länder with relatively high revenues per capita to those with relatively low revenues per capita should further reduce fiscal disparities. From the Länder governments' point of view, fiscal equalization was clearly a redistributive policy. As long as all of them profited from economic growth and the amount of redistributed money remained small, this was acceptable for governments and parliaments in the rich Länder. When the economy went through a series of recessions in the late 1960s and 1970s, and when the structural change of the German economy hit some regions seriously and led to increasing disparities, the redistributive effects of fiscal equalization became an issue of intergovernmental politics. Nonetheless, governments found agreements on amendments of fiscal equalization, not least because the federal government increased its 'supplementary grants' to the Länder. Against their 
original purpose to respond to the fiscal needs of Länder governments, these grants became an additional and growing source to equalize revenues of the Länder (for details see Renzsch 1991).

This policy of incremental adjustment resulted from joint-decision making of federal and Länder governments, the typical mode of multilevel governance in German federalism. In federal legislation on fiscal equalization, the Länder governments are involved via the Bundesrat, which in this case has veto power. In practice, ministers of finance negotiate an agreement, which then is initiated as a bill in parliament and usually passes both legislative chambers. Over time, Länder governments have realized that they profit from speaking with one voice against the federal government. In order to find a compromise on horizontal equalization, the ministers turn this redistributive problem into a positive-sum game by linking horizontal equalization with vertical equalization. They either request an increasing share of the VAT revenues for the Länder or an increase of federal grants. Confronted with the united Länder governments and their veto power, the federal government usually concedes to bear the fiscal burden which an agreement among Länder governments implies. Interested in avoiding conflicts and preventing a deadlock, the federal Minister of Finance regularly approves the requested money, aware of the fact that in contrast to Länder governments, the federal government has sufficient power to increase taxes.

This pattern of policymaking allowed governments to cope with the economic and fiscal divide between East and West Germany after the unification of the country in 1990. Starting in 1995, fiscal equalization was applied to unified Germany without notable revisions of the rules. Despite the disparities between Länder, which had been unknown in the West German Federal Republic, and the ensuing fiscal imbalance, this inclusion of the new Länder governments was possible because the federal government granted a large amount of supplementary funds for East Germany (Altemeier 1999; Renzsch 1998). Later, the federal government increased its share with the so-called Solidarity Pact II and the amended fiscal equalization law of 2001. Presuming that the economy in the East should recover and profit from an integrated market, these additional federal grants were determined to incrementally decrease and finally run out at the end of 2019. In consequence, the fiscal equalization system had to be renegotiated by this date. Soon after German unification, disputes among the Länder governments intensified, and some of them instituted legal proceedings at the Federal Constitutional Court. Yet neither the decisions of the Court nor ensuing amendments of fiscal equalization law led to noteworthy changes. Knowing that, sooner or later, the whole system of fiscal federalism was to be substantially revised, neither the federal government nor any of the Länder governments were willing to engage in a substantial reform. However, the longer a reform was postponed, the more 
the pressure increased with the approach of 2019. This deadline finally became a decisive factor affecting negotiations.

In fact, a revision of fiscal federalism had been on the agenda of German politics since the turn of the century. In 2003, the federal and Länder governments decided to engage in a 'modernization of the federal system'. In order to achieve this ambitious project, both legislative chambers set up a 'Joint Commission of the Bundestag and the Bundesrat', with 16 members elected by the federal parliament and the same number of members elected by the Bundesrat, one from each of the Länder governments. The Commission de facto institutionalized the interplay between party politics and intergovernmental relations, which is typical for politics in German federalism (Lehmbruch 2000). Party groups and the Länder executives prepared plenary sessions of the Commission in separate meetings. Delegates of the federal government participated in the Commission without a right to vote, but federal ministries influenced discussions by providing expertise from special departments. The prime ministers of the Länder, who regularly attended the plenary meetings, were assisted by civil servants who provided knowledge in constitutional law. In addition, the Commission invited 12 experts from the academic sector, among them eight lawyers. Like the few members representing Land parliaments and local governments, experts participated as consultative members. Aiming at influencing the decisions on a reform of federalism, several public or private organizations held public conferences on particular matters. Furthermore, interest associations and individual citizens submitted opinions to the Commission. However, there are no indications that these communications mattered. Nor did they alter the character of negotiations between parties and governments, and nor did they affect outcomes. The Commission more or less replicated the usual structures of joint-decision making in German federalism (Auel 2010; Benz 2008, 2016a: 77-86; Burkhart 2009; Scharpf 2009: 69-116).

It was therefore not surprising that the Commission started its work on the premise that the allocation of financial resources between governments should not be changed by the reform. Although the second hearing of the experts and a special meeting behind closed doors concerned fiscal federalism, the Commission decided not to pursue this topic further and in particular not to deal with fiscal equalization. Nonetheless, the Commission failed to come to an agreement on a constitutional amendment, since federal and Länder representatives could not solve their dispute as to how to divide powers in education. Negotiations on reform continued after the 2005 federal elections, when the Christian Democrats and Social Democrats formed a coalition government. The new government introduced the draft, tabled by the two Commission chairs in November 2004, in a slightly revised version as a bill in parliament, which - again with some minor revisions - passed both legislative chambers. 
The constitutional amendment entered into force in September 2006. It modified the distribution of legislative powers and the conditions under which the Bundesrat has a veto right in federal legislation. As to legislative powers, the federal government was pressed to make concessions to the Länder governments by decisions of the Federal Constitutional Court, which revised its interpretation of the subsidiarity clause for concurrent powers in favour of Länder governments (Scharpf 2009: 94-8). However, fiscal equalization was not affected by the reform.

Immediately after this first reform, the Bundestag and the Bundesrat decided to continue the process and installed a second Commission which worked from March 2007 to March 2009. This time, fiscal federalism was to be the main issue to be dealt with. Yet the agenda demonstrated the impact of administration, as it included specific topics like responsibility for road construction and IT infrastructure. Considering fiscal federalism, the Federal Constitutional Court gave an impetus of its own to the reform process. In a judgment on a case initiated by the Land Berlin against the federal government, the court denied the claim of the Land to receive federal assistance to cope with fiscal distress, but required legal provisions to prevent Länder governments from running into such a situation. The Commission took this as a clear order to amend the constitutional rules on deficit spending and to find an early-warning mechanism in budget policy.

Although the Commission took its mission seriously by discussing all aspects of fiscal federalism, including a reallocation of taxation powers, it again excluded fiscal equalization from its agenda. In the end, the main proposal for a reform was a new debt rule as well as a new federal-Länder institution, the 'Stability Council' which became responsible for supervising the budget policy of the federal and Länder governments (Korioth 2016). A group of administrative experts prepared detailed criteria and proceedings, which the Commission and the legislature ultimately endorsed (Heinz 2016). As a result, the second reform of federalism fulfilled the requirement of the Federal Constitutional Court by amending the legal constraints for fiscal policy and by introducing an evaluation procedure for budget policies. However, it again did not address the pending problem of fiscal equalization.

When in 2013 the Christian Democrats and the Social Democrats formed a 'Grand Coalition' government at the federal level, they envisaged advancing negotiations between the federal and Länder governments on fiscal equalization. In their coalition accord, they announced their intention to establish a new commission to deal with fiscal federalism in a broader perspective, including the competences for revenues and expenditures (Coalition Agreement 2013: 95). In fact, this commission never took shape. Instead, fiscal equalization became a primary matter of intergovernmental negotiations. The process followed the traditional pattern of the German version of executive federal- 
ism. Prepared by civil servants of the responsible departments, ministers of finance of the federal and Länder governments met in private to discuss the existing equalization scheme and proposals for its renovation. In this process, a number of experts commissioned by the Länder governments and party groups presented concepts for a renewal of fiscal equalization (Geißler et al. 2015, in particular the articles by Eichel et al., Behnke, Lenk, Geißler, Färber and Scheller). Yet as far as can be assessed from the outside of the process, these proposals had only marginal impact on the negotiations and the outcome.

Already in 2012, before the official start of the reform process, the intergovernmental council of Länder ministers of finance addressed the issue. In October of that year, they met for their annual conference and decided on an agenda for reform. Effective work eventually commenced in summer 2014. At that time, heads of Länder governments and the federal chancellor discussed fiscal equalization in a meeting, which indicates that the topic had gained priority in the politics of federalism. The heads of government mandated the ministers for finance to elaborate reform proposals. At the same time, they agreed that negotiations should proceed in private, without including representatives from local governments or experts. However, until the next official meeting of the Chancellor and the Länder premiers in December 2014, there was neither an agreement in sight nor any substantive proposals on the table.

In the meantime, the federal Minister of Finance stepped in with the intention to advance negotiations on fiscal relations between federal and Länder governments before distribution between the Länder should be dealt with. Together with the mayor of the city state Hamburg, he published a paper that suggested sharing the surcharge on income tax, which the federal government introduced after German unification, with Länder and local governments and to relieve the Länder governments from expenditures for a number of social services. However, most Länder governments rejected the proposals, and thus the federal Minister's initiative failed. In consequence, the federal government left it to the Länder ministers to find an agreement on equalization among the Länder before it would resume negotiations on federal-Länder distribution. To advance the reform, the federal Minister of Finance signalled that the federal government was willing to concede an additional share of the VAT revenues to the Länder, which should amount to 8.5 billion euros.

In September 2015, CDU- and SPD-led Länder governments issued contrasting proposals, the former aiming at abolishing horizontal transfers between the Länder and the latter abolishing the reallocation of the VAT fund. At this time, party politics seemed to divide the Länder and weaken their bargaining position against the federal government. Yet it did not take long for them to come to a joint proposal, which was achieved finally in December 2015, after several meetings of the Länder prime ministers (Bösinger 2016). The paper presenting the agreement among the Länder governments was telling. Beyond 
listing a number of suggestions for amending the constitution and the law on fiscal equalization, it contained a table showing the prospective fiscal effects of the envisaged amendments. The results of the calculation revealed on the one hand that Länder governments regarded the outcome in terms of money as decisive. On the other hand, they expected that all of them should be better off compared to the status quo and that the federal government should bear the burden of around 10 billion euros per year, i.e., more than conceded by the federal Minister of Finance thus far.

In the subsequent year, the Länder and the federal governments resumed their negotiations. At the end, the federal government accepted the Länder proposal, but not without tabling additional issues to be included in a package deal. In compensation for the extra money that it was required to provide, the federal government demanded new powers in highway administration and rights to control the spending of federal grants and the implementation of tax law by Länder administration. Given the pressure to find an agreement and to renew the law on fiscal equalization, the Länder governments had no alternative but to accept.

When the reform on fiscal equalization had passed the federal legislature with a majority in the federal parliament and the unanimous assent of the Bundesrat in June 2017, it was praised as a major breakthrough because it abolished the former horizontal equalization between the Länder. On closer inspection, the law only revised the procedures for equalization. Instead of transfers from so-called donor to recipient Länder, fiscal disparities are now reduced by a reallocation of an increased Länder share of the VAT revenues, with the per capita share being reduced for the rich Länder and increased for the poor Länder. The principles and rules of distribution remained the same, although the law modified details of the calculation of fiscal capacities. Effective changes concerned the supplementary federal grants. Those dedicated to supporting the transition of the state-controlled economy towards a market economy in the East German Länder were replaced by grants for Länder with fiscally weak local governments and with deficits in research funding. The package deal implemented with the law also continued other special grants.

There is no indication that ministers and heads of governments discussed the principles of fiscal equalization or intended to revise them. Throughout the negotiations, they focused on the measurable outcome. Apart from the above-mentioned paper presented by the Länder governments in December 2015, another aspect is revealing in this respect. Part of the federal government's share of the additional 10 billion euros was achieved by a redistribution of the VAT revenues between both levels of government. According to the constitution, this should be done in response to developments in the revenueexpenditure ratio of governments. Now it was clearly used to avoid negative 
redistributive effects of the reform for individual Länder governments. The law determines the VAT shares of the federal, Länder and local governments for the coming years and beyond 2027 as fixed amounts. This indicates that the development of future revenues and expenditures no longer matters as criteria and that the outcome reflects a deal among bargaining executives. No justification is provided in the publicly available materials.

The new fiscal equalization in Germany can hardly be considered as innovative. After three reform processes and long discussions, governments came to an agreement under the pressure of time (Benz and Sonnicksen 2018: 150-51). Although the reform came with an amendment of no less than 13 provisions of the constitutional law, it did not change the existing system substantially. It improved neither its effectiveness regarding the existing fiscal disparities nor its transparency or fairness (Lenk et al. 2017). When the federal Minister of Finance introduced the bill in parliament, he declared:

What we did not achieve in these negotiations was an agreement that would make the overall system, the complicated system of equalization between the federal government, the Länder and the municipalities, a bit more transparent, a bit more systemic as well as more predictable and, above all, to improve incentives in the system. That was the ambitious plan of the federal government. In any case, we have not come to a resounding success, to say it cautiously. (Deutscher Bundestag 2017: 21769 , translation $\mathrm{AB}$ )

Overall, attempts to modernize in German federalism ended with incremental change. The three stages combine in a particular sequence of policies which did not lead in an intended direction, but at the end appears contradictory and finally backward oriented (Benz and Sonnicksen 2018). Unintended by policymakers, the sequence developed when parties and governments reacted to disappointing or problematic outcomes of the reform processes by starting a new round of negotiations. Throughout this sequence, the pattern of traditional intergovernmental policymaking of political executives and their specialists in administration increasingly gained ground. The first reform commission can be interpreted as an attempt to institute a new arena of constitutional policy, but actually it only replicated the traditional federal-Länder bargaining. More than the first, the second commission insulated the intergovernmental arena against external influence. In the third stage, governments definitively returned to the traditional intergovernmental mode among executives. Like the actors involved, the issues addressed and the reform ambitions shrank from one stage to the next, although the problems of federalism remained the same. Whereas the increasing exclusivity of the actor constellation would have been appropriate if the reform had proceeded in consequential steps - from negotiating constitutional principles and rules, followed by implementation of the revised constitution in specific laws (as observable in the Swiss case, addressed further 
below) - this logic has not guided the course of federalism reform in Germany. Rather the process can be explained by failures to solve problems in previous stages when important issues had been postponed. Concerning the fundamental problems of fiscal federalism, these efforts were doomed to fail.

\section{REFORM OF FISCAL EQUALIZATION IN AUSTRALIA}

As in Germany, fiscal equalization has a long tradition in Australia. In both countries, the evolution of social policy in the late 19th century shaped the federal system, although in a different way. In Australia, the long hegemony of the Australian Labor Party expressed a broad consensus in society on a welfare state based on ideas of social liberalism (Sawer 2000). These ideas justified the highly equalizing allocation of federal grants to states ${ }^{1}$ which the federal government had granted since 1933. After 1999, this 'top-down' approach was transformed into a coherent system of fiscal equalization, including consolidated specific federal grants. This result was not achieved in one single step but in two separate reform processes. Although not intended as a consequential sequence, the second reform complemented and advanced the first one.

The relevance of fiscal intergovernmental transfers and fiscal equalization can be traced back to two particular features characterizing Australian federalism. First, since the foundation of the Commonwealth of Australia, the division of power has caused a significant vertical fiscal imbalance to the benefit of the Australian government. This imbalance increased over time. Nowadays, the federal government collects a large share of taxes, whereas the states and local governments are responsible for delivering and financing public services. In consequence, they are dependent on federal grants. Second, the federal government used the allocation of grants to states as a tool to hold together the federation, which during the first decades of its existence was threatened by a divide between Western Australia and the rest of the country. In contrast to the cultural conflicts with Aboriginal peoples, this divide had its roots in divergent economic structures and conflicts on the allocation of fiscal resources. In 1933, the government of Western Australia organized a referendum in which the people had to decide on a proposed secession from the Commonwealth. Although a majority of voters supported secession, it was never implemented by the Labor government which came to power in the state immediately after the referendum. Instead, the state and federal governments settled the conflict with an agreement which foresaw an improvement of horizontal fiscal distribution of federal funds to the states. The federal government established the Commonwealth Grants Commission (CGC) which was commissioned to determine the fiscal needs of states claiming federal assistance. Since then, the CGC, an independent body of experts from the public sector, guaranteed continuity in the redistribution of funds (Williams 2005). 
The CGC designed a policy supporting states with 'fiscal disabilities', thus applying a needs-based approach to distributing federal funds (McLean 2004: 22-3). Right from the beginning, the Commission's work was guided by the aim to enable state and local governments to provide public services according to equal standards. This was in line with the egalitarian attitudes of Australian people, which resonated in social policies of the early 20th century that were approved by both the Liberals and the Labor Party (Sawer 2000: 301-7; Swain 2013). Since the 1980s, the Senate and the High Court defended this policy against neoliberal trends which prevailed at that time (Castles and Uhr 2007: 114). In 1973, federal legislation endorsed the CGC's policy by stating that federal assistance should enable a state, by reasonable effort, to provide services on a standard not significantly diverging from the standards of other states. While these rules and the 'epistemic authority' of the CGC contributed to legitimize fiscal federalism, the Australian government used special purpose grants to intervene in states' policymaking. Corresponding to general tendencies in the jurisprudence of the High Court on federalism (Aroney 2017), this practice contributed to an increasing centralization of powers. However, although there are certainly good reasons to consider Australia as a centralized federation (Fenna 2012b), one should not overlook the fact that states retained their competences to provide public services, with a few exceptions such as responsibility for tertiary education (Braun 2011). Therefore, not unlike in Germany, the evolution of federalism in a welfare state has led to a division of functions between levels of government with centralized legislation and decentralized implementation. The interdependence between these functions and fiscal imbalances increased the need to coordinate policymaking in multilevel governance, in which the Australian government clearly is in a leading position vis-à-vis the state governments.

Significant changes occurred after 1990, when the federal government turned from a hierarchical towards a more cooperative approach of governance. Regardless of whether Labor or the Liberal and National Party were in power, the federal government in principle accepted this approach. In 1992, Prime Minister Bob Hawke initiated the foundation of the Council of Australian Governments (COAG), a standing intergovernmental forum (Phillimore and Fenna 2017). This core institution of the new cooperative federalism became the central venue where federal and state governments negotiated and concluded intergovernmental agreements, among them the 'National Competition Policy' and the 'Mutual Recognition Scheme', which both aimed at advancing an integrated market (Painter 1998). As in a typical joint-decision system, the Council's decision rules require the assent of all governments. With few exceptions, governments have applied these rules and implemented agreements (Anderson 2008; Towmey and Withers 2007: 29). Although the existence of the COAG itself was founded by an intergovernmental agreement, 
its operation depends on the voluntary participation of governments, and its decisions cannot bind the federal or state parliaments.

The COAG was established as an institution to promote reform. Considering Australian federalism, a substantial reform was accomplished with the Intergovernmental Agreement on the Reform of Commonwealth-State Financial Relations. This agreement, signed on 9 April 1999 by members of the COAG, significantly changed horizontal fiscal equalization. The reform process started with negotiations between the federal and state executives, when governments realized the need to consolidate sales taxes and excise duties, which so far had been collected by both the Commonwealth and the states. State taxes had been levied on a shaky constitutional basis. In 1997, a decision of the High Court of Australia invalidated state franchise fees on petroleum, tobacco and alcoholic products. In order to cope with the detrimental consequences of this court ruling, the federal government announced a renovation of the system. The centrepiece of this reform was a new Goods and Service Tax (GST), which was to replace diverse sales taxes. After a series of meetings of the prime ministers and a special Premiers Conference in November 1998, the agreement was settled.

This intergovernmental agreement not only changed the tax system but also revised fiscal equalization. The new GST, introduced by a law which was passed in parliament in March 1999, is collected by the federal tax administration, but distributed, on a monthly basis, to the states (for details see Spasovejic and Malcolm 2013). It alleviated the dependence of the states on special grants and on the will of the federal government and instead established a reliable fiscal resource. Consistent with the intergovernmental agreement, the federal law also states that the rate and the basis of the GST should not be altered without the consent of all state governments. In turn, state governments agreed to abolish a number of indirect taxes. The GST revenues are distributed among individual states on the basis of valid principles of horizontal fiscal equalization to ensure that all states have the capacity to provide an approximately equal level of services to their residents. The precise shares of the GST for individual states are determined by a joint decision of the COAG following a recommendation of the $\mathrm{CGC}$.

A further amendment of fiscal relations in the Australian federation concerned the special purpose grants (Fenna 2012a; McQuestin 2012, 2014). It was initiated by Labor Prime Minister Kevin Michael Rudd. In December 2007, about one month after his election as head of the federal government, Rudd announced key elements of his reform programme in a meeting of the COAG. The federal government initiated this reform in order to gain control over states' expenditures and policy outcomes. It intended to change the rules for providing conditional grants according to section 96 of the Constitution. Before this reform, the federal government co-financed specific, narrowly 
defined purposes, and the grants had been spent via line administration without involvement of the Treasury. The federal departments used them as instruments to precisely prescribe a policy which state governments had to implement. Moreover, they could penalize ineffective implementation by withholding money. This coercive mode of intergovernmental relations was considered not only as centralist, but also as ineffective and non-transparent. Since about 2000, state treasurers issued proposals for a reform of the grant system, and later the COAG and think tanks joined in the discussion and encouraged the federal government to adopt a more cooperative grant policy. After the 2007 general election, state governments took the opportunity to push for their reform proposals, given the willingness of the Rudd government to change federal grants. Actually, the Prime Minister extended the agenda he had presented during his election campaign, which aimed at more transparency in the policymaking of federal and state governments in ushering in a new era of cooperation. What at first appeared as an abstract idea of a renewed cooperative federalism now turned into a significant and effective modification of fiscal federalism (McQuestin 2014: 105). The Prime Minister initiated a review of the whole system of federal funding of states' policies. The scope of financial reform was extended by an approach to change the administration of grants. Hence, federal and state treasuries, which had a significant interest in the better management of finances spent by line departments for specific purposes, became the central actors in the process.

Again, first ministers were the driving forces of the reform process and the COAG served as the central platform for negotiating the revised intergovernmental agreement. This time, however, federal and state treasurers joined intergovernmental negotiations at the highest political level. Working groups gathering deputy heads of treasury departments turned out to be an important arena to pursue negotiations. They elaborated the reform proposal and reported to the four COAG meetings which took place in 2008. This structure of the reform process signifies the effort to avoid a sectoral division of the reform policy in ministerial councils, where line ministers meet. Representatives of governments still relied on the advice of their administration, but the political nature of the reform process was obvious: 'At many meetings under the Rudd government there were periods where bureaucrats were not even sitting behind the leaders but were outside the room, invited only to be told what decision had to been made rather than, as in the past, what outcome first ministers want officials to reach' McQuestin 2014: 101).

The outcome of the reform continued the horizontal fiscal equalization scheme based on the GST, which was complemented by a revised scheme for federal grants. Instead of the coercive system of funding by more than 100 special grants, the federal government now provides, on a permanent basis, grants for five broad policy areas which include core services of the 
public sector. Based on so-called 'National Agreements', federal grants assist state governments in developing skills and workforce, providing disability services, implementing programmes to prevent homelessness and to make housing affordable, and in advancing health policy reform. Moreover, states can receive additional grants which are determined to initiate and assist policy reforms in their areas of responsibility, provided that they fulfil the aims, benchmarks and procedures negotiated between federal government and the government of an individual state ('National Partnerships'). The payment is based on bilateral agreements between the responsible line ministries of the federal government and the government of the state concerned, and funding is provided for a fixed term. Both types of grants require state governments to fulfil standards or output goals, and the implementation and performance have to be analysed and evaluated by a new COAG Reform Council. Thus, input control by detailed rules and conditions defined by the federal ministers were replaced by monitoring of the service quality and reforms accomplished by state governments.

Whether these policy changes can be considered as significant or incremental depends on the perspective. The intergovernmental agreements as such, the introduction of the GST and related tax reforms at the federal and state level, as well as the consolidation of special purpose grants and the performance based National Partnership payments, combined with the institutional changes in intergovernmental relations, in particular the establishment and evolution of COAG, add up to fundamental modifications of fiscal equalization in Australia, not least when compared to the incremental changes in German federalism. On the other hand, horizontal equalization was continued according to principles and rules that have evolved over decades. These principles still reflect a stable consensus, implying that public services for residents of each state should be guaranteed at a level of quality that does not substantially diverge from the standards achieved in other states. Moreover, the implementation of National Partnership grants has come closer to the former practice of top-down governance pursued by line ministries than to the bottom-up or cooperative approach intended by the reform - the reasons being insufficiently defined performance criteria, the lack of an output-oriented administrative culture, the expectations of parliaments and the public to achieve visible results in the short term, and deficient evaluations of policies (McQuestin 2014: 130-36). In line with this development, the COAG Reform Council, established in 2010 to provide comparative performance data, was abolished in July 2014, and the task of monitoring was delegated to the Department of the Prime Minister and Cabinet. On balance, fiscal equalization reforms in Australia should be characterized as policy innovation without transformative effects. Although intergovernmental agreements had the potential of leading to a significant change in policy, implementation did not conform to the ambitious goals in every respect. 
Since this reform has been accomplished, the system of fiscal equalization proved rather stable and appropriate to cope with economic disparities between Australian states and to diminish the vertical fiscal imbalance in the federation. Until 2019, the COAG has accepted the recommendations of the CGC for horizontal equalization, despite the governments of New South Wales, Queensland, Victoria and Western Australia criticizing their share of the GST as insufficient. Soon after the 2007 reform took effect, federal institutions called for a review of fiscal equalization with regard to its impacts on state services and reform policies. On 30 March 2011, Prime Minister Julia Gillard announced a review of the GST allocation (Warren 2012). A panel of three independent experts, who were commissioned to carry out the review, consulted academic experts, representatives of state governments and other interested parties. In its report submitted to the Treasurer, the experts overall endorsed the existing system and suggested limited amendments (Australian Government 2012). Some years later, disputes revived when Western Australia faced a decline of its revenues that was not immediately compensated by the GST distribution, because regular adjustments of fiscal equalization become effective with a time lag. In response, the Australian government commissioned the Productivity Commission, an independent advisory commission, with an inquiry and to suggest solutions. The Commission issued its report in May 2018 (Productivity Commission 2018) and recommended the reduction in the extent of equalization to the average fiscal capacity of all states. However, after coming to an agreement with state governments, the Prime Minister announced legislation which should introduce a cap for donor states that should prevent them from falling below 75 per cent of their original GST share. In order to avoid negative effects for poorer states, the government increased the fund from its own sources.

Despite continuous discussions and reviews, fiscal equalization has never become a matter of party politics, not least as opinions diverge more within parties than between parties. In academic circles, the system has been defended by some and criticized by others as inefficient, both regarding the incentives for state governments and the bureaucratic costs for the Commonwealth. The calculations of the fiscal capacities and needs in the 'black box' of the CGC has been assessed as overcomplicated and opaque (McLean 2004; Warren 2012). Yet the system was never questioned in total. When in 2015 the federal government under Prime Minister Tony Abbott launched a Discussion Paper on a reform of Australian federalism, started negotiation with the states in the COAG and encouraged a public debate among experts (Bruerton et al. 2017), proposals concerned the allocation of tax powers in order to increase the autonomy of the states, an attempt which finally failed (Carvalho 2021). Fiscal equalization was not a matter of this reform. The basic idea of equalization, to provide public services on an equal standard in all parts of the Australian 
Commonwealth, remains accepted. Policy innovations during the period of cooperative federalism proved sustainable.

Institutional conditions of policymaking and patterns of multilevel governance in Australian federalism resembled joint-decision making in German federalism. Nonetheless, policies of fiscal equalization were revealed to be more innovative than those resulting from reforms we observed in Germany over the last two decades. One reason might be political leadership. In contrast to Germany, where the federal government at best responded to reform pressure from the Länder governments and where chancellors had never been intensely engaged in this matter, Australian prime ministers put federalism at the top of their agenda and promoted a reform of fiscal federalism. To a certain degree, the different role of political leadership can be traced back to institutions, that is, the difference between the consensus type of parliamentary democracy in Germany and the Westminster type that exist, in a modified version, in Australia. In addition, Australian pragmatism - the shared expectation of political and societal actors that problems have to be solved and output is more relevant than formal rules or procedures - clearly contrasts with the German legalist approach (Benz 2008; Hollander and Patapan 2007).

Without neglecting these conditions, other factors appear more important in explaining Australian policy innovation. In Germany, federalism and fiscal equalization had never been based on a clearly expressed and widely shared idea defining their purpose. Fiscal equalization in particular has been steadily contested, and when it came to a revision it was a matter of bargaining on redistribution without any explicit reference to norms of distributive justice. In Australia, this norm emerged very early, and it was preserved by an independent institution, the CGC. Hence the principle of equalization was never seriously disputed. Accordingly, politics of fiscal equalization were about applying this principle, and this task was delegated to the independent CGC, that is, the redistributive policy was 'depoliticized'. When Australian governments focused on reforming basic elements of the system of equalization, such as the funds to be redistributed, the rules for providing federal grants, procedures to implement or evaluate state policies induced by federal grants, and institutions committed with particular tasks, the outcomes in terms of fiscal resources did certainly matter. But as long as governments relied on the rationality of the CGC (Morris 2002) and recurring reviews by experts, the basic consensus among federal and state governments prevailed.

Beyond that, the institutional differentiation of arenas, the parliamentary arena of the Australian government, the intergovernmental arena of the COAG, and the administrative arenas of working groups in the reform process and the CGC in implementing fiscal equalization has led to the compensation of party competition and intergovernmental bargaining by deliberative processes. Moreover, although not planned, the system of fiscal equalization was changed 
in two consequential steps, and both addressed institutional conditions of the policy. This institutional and temporal differentiation of policymaking, in combination with the path-dependent evolution of the guiding principle and its institutionalized basis in the CGC, can explain the rather successful reforms and innovative policy, whereas the complementary structure of monitoring and reviews by independent bodies can explain the continuity of the adjustments.

\section{NEW FISCAL EQUALIZATION IN SWITZERLAND}

In Switzerland, fiscal equalization appeared on the agenda of federal politics in the context of efforts to comprehensively reform the constitution. During the 20th century, the decentralized federal system with its small cantons and local governments had to be adjusted to the requirements of a modern welfare state and an internationally competitive economy. However, Swiss citizens tended to prefer decentralization, although they often voted for the centralization of power in constitutional referenda (Vatter 2018: 169-86). A comprehensive revision of the constitution had been on the political agenda since the 1950s, including a territorial reorganization of the federation. A 'creeping centralization' (Kriesi and Trechsel 2008: 35) and the increasing interlocking between federal and cantonal politics and policymaking became a matter of continuous debates. However, when the federal council (Swiss government) finally initiated a comprehensive overhaul of the constitution in 1985, it excluded the allocation of power and fiscal equalization from the project. These issues should be addressed in a separate reform process (Freiburghaus 2012: 55).

Fiscal equalization became an issue of constitutional policy in 1991, when federal and cantonal executives, assisted by experts, raised doubts that the federal grants to cantons reduced horizontal fiscal imbalances (the following is based on Benz 2016a: 70-77; Braun 2009; Freiburghaus 2012; Vatter 2018; Wettstein 2012). A report published by the Federal Department of Finance revealed not only a confounding practice of co-financing cantonal tasks, but also endorsed the assumption that these transfers widened rather than diminished the fiscal gap between poor and rich cantons (Wettstein 2012: 81). In consequence, federal and cantonal governments agreed that fiscal relations had to be revised. They also concluded that in order to restore the federal balance, intergovernmental cooperation and the allocation of power also had to be addressed. The agenda of the reform therefore covered all three issues, so that separating them would not be an option for the actors involved.

The Federal Department of Finance initiated official negotiations on a constitutional reform, which started in 1994 within the Conference of Ministers of Finance of the cantons. They adopted the agenda which civil servants of the Federal Department of Finance had proposed. Negotiations did not follow an explicitly determined policy design. Instead, they evolved in line with the 
standard operation procedures of Swiss government and politics, institutional rules of constitutional amendment and pragmatic decisions in response to particular situations. In retrospect, however, the process revealed a certain logic and proved effective. This explained the significant change of the federal constitution, in particular of fiscal equalization.

Soon after the reform process had started, the federal and the cantonal governments set up a 'project organization' to analyse the problems of Swiss federalism and for drafting the framework of the reform. It was headed by a project team which guided specialized working groups and integrated their conclusions in reports. The sub-units of this organization included civil servants from the federal financial administration and the cantonal administration. The project team submitted the results of the working groups to the federal and cantonal ministers of finance and, subsequently, to the Conference of Federal and Cantonal Governments.

Instead of focusing on the redistribution of power and finance right from the outset, the executive first elaborated 'Guidelines' for the reform. They defined the general approach and basic principles. In view of the professional background of civil servants and participating experts, it was not surprising that theories of fiscal federalism and new public management had a strong impact on the framework. However, this was not a theoretical concept; it defined in a pragmatic manner the key concepts for a comprehensive and coherent revision of federalism. Moreover, the framework provided the reasons for a change in power and fiscal equalization.

The final version of the guidelines was discussed and approved by the federal government and the Conference of Cantonal Governments. It was then subject to public consultation. Cantonal governments, political parties and civil society organizations were invited to participate, and more organizations than those officially addressed submitted opinions. The consultation proved to enjoy widespread support for the reform and a broad consensus on the guiding principles.

Following this consultation, a second phase of the reform started in 1997. The project organization was adjusted to the new task and committed to transform the guidelines into proposals for detailed revisions of the constitution. The team coordinating the project presented its final report to the federal and cantonal governments. When the governments had approved this report, it was again published for the consultation of cantons, parties and civil society. In this process, some groups raised objections against particular proposals. After settling the disputes in bilateral negotiations and in the intergovernmental process, the executive elaborated drafts for a constitutional amendment bill and ordinary bills on fiscal equalization. In November 2001, the federal government introduced the drafts in the legislature and thus gave the parliament a voice in the process for the first time. Some criticized the reform process 
as dominated by experts and the bureaucracy. However, members of federal and cantonal parliaments had ample opportunities to get involved either in public consultation or in informal contacts to the executive, which they used (Wettstein 2012: 89).

The draft proposal finally passed the federal legislature and then was subject to the required constitutional referendum, which took place in November 2004. Apparently, governments and parties succeeded in convincing a clear majority of Swiss citizens in the referendum campaign. Sixty-four per cent of citizens casting their vote approved the amendment, including a majority of voters in three of the six cantons which the new fiscal equalization burdened as net payers. The low turnout (35.5 per cent) signified that citizens accepted the reform and that no important group or party mobilized opposition (Freiburghaus 2012: 75). When the constitutional amendment was in force, the reform was implemented in legislative and administrative decisions.

Compared to similar constitutional reforms in other federal or regionalized states where joint decisions of central and regional governments had to secure the required qualified majority in legislation (Benz 2016a; Benz and Knüpling 2012), the outcome of the Swiss reform was astonishing. It not only substantially changed the distribution of powers between the federation and the cantons and introduced new rules for inter-cantonal cooperation in order to make decentralized policies more effective, but in particular it introduced a new and widely accepted system of fiscal equalization. Inter-cantonal redistribution and the allocation of federal grants follow clear criteria related to fiscal capacities and the fiscal needs of the cantons. Ultimately, the federal government had to concede additional long-term compensations for those cantons which on balance lost financial resources by the reform compared to the status quo, but still the new fiscal equalization scheme evidently improves fiscal federalism in Switzerland significantly. The transfers are no longer allocated as specific grants, but as general grants in order to equalize fiscal resources and to compensate for the particular burdens of individual cantons. Fiscal equalization addresses disparities of both revenues and expenditures in a coherent system. Although some cantonal governments regularly complain about the horizontal redistribution of revenues, the reform has contributed to stabilizing Swiss federalism against tendencies towards centralization and fiscal imbalances. It has changed the constitutional status quo significantly. The positive public evaluation and the unproblematic implementation process indicated a successful policy change in line with the intentions of governments.

This policy innovation is even more astonishing on account of the constraining institutional conditions of multilevel governance established by Swiss federalism and democracy. In contrast to parliamentary federations in Australia and Germany, the consensus democracy in Switzerland, where positions in the federal cabinet are distributed among mainstream parties 
according to proportional rule, allowed the federal and cantonal governments to proceed without the pressure of elections or the competition of vote-seeking parties and government-vs.-opposition dynamics. Therefore, the executive had all the time to elaborate a reform proposal and to manage conflicts. Parties expressed different opinions on particular aspects of the reform, but disputes had not been ignited by election campaigns. The political culture facilitated negotiations aiming at a consensus among all political and societal groups (Freiburghaus 2012: 76). However, these particular institutional conditions alone cannot explain the fact that significant redistributive conflicts, which in similar cases obstructed ambitious constitutional reform projects, could be managed. Therefore, other conditions need to be considered. What is striking in this case is the differentiated structure of constitutional negotiations, which went through expert-dominated, intergovernmental, parliamentary and consociational processes (Wettstein 2012).

Upon closer inspection, this process not only stands out for its long duration, but also for its organizational features. While constitutional politics and normal politics are hardly distinct in the consensus democracy of Switzerland, the process of reforming federalism and fiscal equalization differentiated them. This was achieved, first and foremost, by the decision to proceed sequentially. The first sequence of the reform focused on the aims and general principles guiding the renovation of federalism. After they had been fixed, the second sequence focused on the details of constitutional amendments. Finally, after amendments had been ratified, legislation and executive decisions implemented the new constitutional rules. This sequential process implied that the process of policymaking was divided and took place in distinct arenas.

A comprehensive change of a federal constitution runs the risk of failing because of its complexity. By affecting a variety of interests of powerful actors, it tends to favour bargaining on package deals. Yet the sequential process organized in Switzerland implied not only a temporal but also a substantial differentiation of negotiations. By separating decisions on principles from decisions on a redistribution of powers and on new rules for financial transfers, the process prevented distributive bargaining among governments dominating from the outset. In negotiations on the guidelines, all actors developed a shared understanding of the general premises and the normative framework justifying the reform. This differentiation of constitutional principles and rules created a 'veil of ignorance' (Freiburghaus 2012: 77) concealing redistributive consequences in the first phase. Therefore, the arguing behaviour of all actors involved predominated in negotiations and encouraged participants to find a basic consensus. In the ensuing negotiations dealing with the details of fiscal equalization and the particular powers to be reallocated, this consensus on a normative framework significantly reduced the scope for distributive bargaining. Although representatives of cantonal governments now tried to 
gain as much as possible for their canton, they had to justify their claims as being in accordance with the guidelines.

Another characteristic feature of the Swiss reform process was a differentiation between the administrative and the political tier of the executive, and between executive, parliamentary and consociational arenas. As outlined above, the federal government set up a project team responsible for managing and coordinating the committees and sub-committees of the federal-cantonal Conference of Directors of Finance, which worked on specific aspects of the reform. Thus, from the very beginning, civil servants from the federal and the cantonal ministries of finance cooperated closely, supported by academic experts who provided the theoretical basis for the reform programme. These actors shared the mission to achieve a significant reform of Swiss federalism and, as a team, promoted the reform. Next, ministers of finance and heads of government negotiated on the proposals, and their agreements legitimized the proposal submitted by civil servants. In a further step, the reform guidelines and, in the second stage, the legislative package elaborated in the executive were discussed with representatives from interest groups, as required by the established practice of Swiss democracy. Finally, the legislature debated and voted on the reform. Both the decision on principles (the guidelines) and the decision on detailed amendment proposals passed these four arenas.

As in Germany, the reform of fiscal equalization in Switzerland implied constitutional amendments, and thus the negotiated agreement had to be ratified according to amendment rules, that is, by both houses of the federal legislature and in a referendum. In the Swiss consensus democracy, however, neither parliamentary decisions nor outcomes of a constitutional referendum are determined by the negotiated proposal. Majorities in both houses of the legislature result from issue-specific coalitions among parties in parliament. Therefore, governments cannot rely on the support of a majority or anticipate vetoes in legislature when negotiating an amendment bill. But for the same reason, constitutional negotiations are hardly burdened by party confrontation. Executives can also not anticipate how people will vote in a referendum, despite consultation with interest organizations which can mobilize their members. Therefore, while promoters of a reform can negotiate without being committed to party positions or interest groups, they have to provide compelling reasons in the legislative process and in particular in the referendum campaign. At the same time, governments, parties and civil society organizations supporting the reform have to convince citizens in public discussion by explaining the rationale of the reform rather than declaring what they may gain or lose. Ratification thus constitutes another arena of communicative interaction (Linder and Mueller 2021: 173-86).

The different arenas of deliberation, strategic bargaining, consultation and decision making were linked in such a way that policymaking increasingly 
opened up to new actors and to a wider range of interests. It started with exclusive, 'technocratic' negotiations among specialists, and continued with including political representatives, before parties, organized interest groups and civil society participated. Thus, the process became more and more inclusive. This way, it not only generated legitimacy but at the same time made the complexity of affected interests manageable. Overall, the process comes close to the model of 'negative coordination' (Wettstein 2012: 86-7), which allows affected actors to raise objections to a proposal but not to participate in the elaboration of the proposal. In fact, it combined 'positive coordination', that is, negotiations among federal and cantonal executives, with negative coordination in parliamentary and consociational arenas. This arrangement appears to be most effective for dealing with complex issues (Scharpf and Mohr 1997).

Also remarkable in the Swiss case is the loose coupling of arenas linked in the sequence of the reform process. Politics in executive negotiations do not determine the democratic process, which on the other hand does not determine but influences the pre-parliamentary process. The actors negotiating on a constitutional reform had to search for the presumed general will of the people; they could not behave like agents of veto players, that is, parties or parliamentary coalitions. Although fiscal equalization was about winning or losing in a redistributive policy, experts, civil servants and representatives of governments at all levels acted cooperatively, and cooperation was the appropriate strategy to find acceptance in legislation and in the referendum. The shadow of majority decisions which are difficult to anticipate in Swiss democracy explains the particular culture of consensual policymaking, a culture generated and reconfirmed in institutions and in the political practice of the political system. This culture is unique to Swiss federal democracy. Nonetheless, the successful innovation of fiscal equalization cannot be explained by this culture alone. It was the particular organization of multilevel policymaking which appears essential to cope with the intricacies of redistributive policy.

This multidimensional differentiation of arenas and processes did not rule out bargaining processes and strategic interaction determined to promote particular interests. Governments of the economically well-off cantons, which expected to lose under the new fiscal equalization scheme, supported the reform, albeit unwillingly, but only after the federal Social Democrats had announced their intention to introduce a bill on tax harmonization and thus threatened to reduce the tax autonomy of the cantons. Furthermore, the Federal Department of Finance accommodated opposition from these cantons by compensating reduced transfers for a long time (Cappelletti et al. 2014). Concerning the envisaged separation and decentralization of power, the federal and cantonal governments finally accepted more power sharing than originally intended (for details see Freiburghaus 2012: 67-70). After the reform, debates among cantons and the federal government have continued, further changes 
have been suggested, and some adjustments have been accepted (Vatter 2018: 199-203). However, intergovernmental bargaining and compromises never deviated from the principles and reasons justifying the reform. The basic goals, the guidelines, the overall substance designed in the agenda and the coherence of the project could be maintained. By moving from one arena to another, governments found increasing support for the reform project, as they had to justify their proposal repeatedly. By communicating the reform in media campaigns, the federal executive contributed to this generation of a consensus on the reform.

\section{CONCLUSION}

The results of fiscal equalization policy in the three federations differ according to the scope of change compared to the status quo, the conformity with the policy agenda, the innovativeness of the guiding ideas, and the sustainability of policy change. In Germany, the fiscal equalization system was only modified in details, although the replacement of transfers from so-called donor to recipient Länder by deductions from, and additions to, the VAT revenues of individual Länder was meant to be substantial. In processes of decision making, there was neither a real agenda nor any defined ideas guiding the reform. The new law should remain valid for at least ten years. In Australia, the consolidation of a number of indirect taxes, the introduction of the GST, and the substantial revision of federal grants significantly changed the existing fiscal equalization system including the institutional framework. The reform was implemented as planned and guided by ideas derived from a 'social-democratic' approach to fiscal federalism. So far, the system has survived attacks from state governments and critical evaluations. In Switzerland, a new system of fiscal equalization replaced non-transparent federal grants in a reform process which from the beginning followed a clear agenda and ideas of 'liberal' fiscal federalism (for details on these ideas, see: Harmes 2019: 30-56). In line with these ideas, equalization still leaves disparities between cantons (see Table 6.1) and does not undermine tax competition among them. Despite ongoing debates and a recent review of the new fiscal equalization, the system seems rather stable.

To explain change, many conditions are mentioned in the literature. All the reforms followed a recession in the economy; in Germany, however, with a significant delay. Here, the pressure of time due to the sunset clause of the existing law finally pushed policy change, but it cannot explain the substance of change. Changes in government had an impact in Australia, but not in the other federations. The Federal Constitutional Court repeatedly influenced debates on fiscal equalization in Germany, but it did not intervene in the last reform process. Likewise, a High Court ruling provided an impetus in Australia, but this did not require a reform of fiscal equalization. In all cases, 
we find triggering events but no critical juncture or focusing events. Finally, the duration of the process did not really matter. The most innovative policy of fiscal equalization in Switzerland resulted from a process, which started in 1994 and finally ended in 2008 when the new system was in place. In Australia, two reforms emerged after comparatively short negotiations, but the overall change took about a decade to be accomplished. In Germany, the fiscal equalization reform which was passed in 2017 had been an issue since at least 2012, after it had been postponed in previous reforms of federalism.

All these factors cannot explain the different qualities of policy change. What makes a difference is how the process was organized in the multilevel systems. Remarkably, the most complex process, which we observe in Switzerland, has led to the most innovative outcome. A process which replicated the routinized joint-decision making in the executive has constrained policy change in Germany. Here, political representatives of the Länder negotiated a compromise, followed by a compromise in negotiations of the Länder with the federal government. The federal parliament saw no chance to modify the reform proposal of the executive, not least as it was supported by the Bundesrat. In consequence, the recent reform of fiscal equalization followed the tradition of incremental policymaking. In Australia, the intergovernmental arena dominated as well, but the process of intergovernmental negotiations was depoliticized by a differentiation between the political and the administrative arenas. In Switzerland, the organization of the policy process combined arenas of political bargaining with those where experts argued on reform options, and the loosely coupled arenas maintained their unique patterns of interaction. The sequencing of decisions on principles and decisions on constitutional and legal rules further limited institutional constraints and strategic action in intergovernmental or party-political processes.

\section{NOTE}

1. In this section, the term 'states' refers to the six Australian states (New South Wales, Queensland, South Australia, Tasmania, Victoria, Western Australia) and - for reasons of simplification - includes the two self-governed territories (the Australian Capital Territory and the Northern Territory). 